\title{
ERRATUM
}

Fritz Neuweiler · Daniel Bernoulli

\section{Mesozoic (Lower Jurassic) red stromatactis limestones from the Southern Alps (Arzo, Switzerland): calcite mineral authigenesis and syneresis-type deformation}

\section{Int J Earth Sci (Geol Rundsch) (2004) 94:130-146}

In the printed version of the article, a small piece of text was unfortunately omitted. Page 141, 1st column, line 10. From there, the text reads as follows:

...For all samples, $\mathrm{Zr}$ strictly covaries with $\mathrm{Hf}(97 \%$ $\mathrm{Zr}$ to $3 \% \mathrm{Hf}, R^{2}=0.98$ ), whereas only marly lithologies have absolute $\mathrm{Zr}$ contents $>5 \mathrm{ppm}$ (Fig. 15). Only for these samples $\mathrm{Zr}$ negatively correlates with $\mathrm{Y} / \mathrm{Ho}$-ratios indicating a terrestrial signature, whereas for $\mathrm{Zr}<5$ $\mathrm{ppm}$ terrestrial input is negligible. Interestingly, at low $\mathrm{Zr}$ contents highly variable $\mathrm{Y} / \mathrm{Ho}$ ratios (34 to 51) are evident (Fig. 15). These rather pure.....

We also apologize for the reduction of several of the figures to postage-stamp size that occurred during final production by Springer.

The online version of the original article can be found at http:// dx.doi.org/10.1007/s00531-004-0442-3.

F. Neuweiler $(\bowtie)$

Department of Geochemistry, Geoscience Center,

University Göttingen, Goldschmidtstrasse 1,

Göttingen, 37077, Germany

E-mail: fneuwei@gwdg.de or fritz.neuweiler@ggl.ulaval.ca

D. Bernoulli

Department of Earth Sciences, University of Basel,

Bernoullistrasse 32, Basel, 4056, Switzerland

E-mail: daniel.bernoulli@unibas.ch

Present address: F. Neuweiler

Institute for Paleontology, University Erlangen,

Loewenichstrasse 28, Erlangen, 91054, Germany

F. Neuweiler

Département de géologie et génie géologique,

Pavillon Pouliot, Université Laval, Québec, G1K 7P4, Canada 